the alternatives which guide future action, or is this step left to only a few people near the apex of the organization? Does the staff member participate in decisions involving large "sunk" costs or long-range action, or is he limited to decisions affecting short range activities and committing only a small portion of the organization's resources?

Libraries, with one or two exceptions, are relatively small organizations-and small organizations may call for different techniques for staff participation in management from those we usually find described in business literature. Also, libraries are organizations composed of professional and non- professional personnel engaged closely together in an educational service. Personnel administration in such organizations might be different from a factory or typical office installation.

The participants come to us with entirely different library work experiences. Mr. E. Hugh Behymer discusses the problems of administration and management in the small college library, where the functions of management and actual operation are frequently embodied in one person. Dr. Keyes Metcalf points out some of the highlights of his career, particularly as they relate to staff participation in management.

By E. HUGH BEHYMER

\title{
The Dilemma of the Small Liberal Arts College Library
}

T HE SMALL LIBERAL ARTS COLlege is a unique American institution. It functions in a way and for a purpose different from educational institutions of the traditional university pattern. It occupies such a familiar place in the pattern of higher education in the United States that it is accepted but not always understood. The liberal arts college is an educational institution separate and distinct from teacher training colleges, technical schools, vocational schools, and professional schools.

A liberal arts college, in the American sense of the term, is an academic institution for higher learning which has certain requirements for entrance, offers courses leading to the bachelor's degree in the liberal arts and sciences, and trains its students in the art of living. Entrance requirements, except in some isolated instances, are those educational certifications represented by the usual four-year high school course or its equivalent. Both should be, and generally are, broad enough and flexible enough to take care of the individual needs of the various applicants for admission. The training given offers a broad, general educational background, leaving how to make a living

Mr. Behymer is librarian and associate professor of librarianship, C. W. Post College, Long Island University. to the technical and professional schools. The liberal arts college differs from a university, a technical school, or a professional school in its objectives, size, and end product. If it does not differ in every instance in all three, then specifically in at least one. It can be stated that among others the following objectives characterize the liberal arts college: (1) to impart basic knowledge to its matriculates and to develop attitudes and skills which may contribute to effective and personal group living; (2) to establish a foundation for critical thought through investigation, experimentation, and reading; (3) to stimulate an appreciation for the social and cultural contributions of mankind; (4) to develop an appreciation within students for good literature and the fine arts.

These objectives may, of course, be a part of the objectives of a university, but it is suggested that they may conceivably apply specifically to that part of the university known as the "college." These objectives do not include all the objectives of all liberal arts colleges, but they are those most usually accepted.

Throughout the United States there are a great number of academic institutions which call themselves liberal arts colleges. Based exclusively on enrollment they range from about two hundred students to several thousand. After careful consideration, it has been 
arbitrarily decided to call a college small that has approximately five hundred students regularly enrolled, and with forty full-time faculty members. A few more students or faculty members would not necessarily affect the end result and a few less would keep an institution well within the definition.

What is a college library? It is a living, growing collection of books, periodicals, newspapers, and related materials, designed to meet the changing needs of its users for specific information, general information, and recreation. Important factors are the staff, the budget, and the quarters in which the collection is housed, but fundamentally the books and the users constitute the library. It has been arbitrarily decided to call a liberal arts college library small that has approximately 50,000 volumes, three fulltime professionally trained assistants, and a budget of $\$ 25,000$ per year.

The dictionary defines administration as "the managing or conduct of an office or employment; the performance of executive duties." In simplest terms administration is actually determined or planned action taken in pursuit of conscious purpose. Administration is the science and art of conducting an enterprise with maximum efficiency and minimum cost. Administration properly conducted not only considers ways and means but also weighs values and determines ends to be sought. Administration and management are not the same thing: the function of administration is to determine corporate policy, to coordinate finance, production, and distribution, and to point out the path to be followed; management is the execution of the policy set by the administration. The essence of administration is to plan systematically work within the confines of a predetermined program and then translate these goals and endeavors into positive achievements.

The use of the word "organization" must here have two distinct and separate connotations. The first is the place the library occupies in the college, and secondly it must mean the technical organization of the library itself. Basically, the role of the librarian as an administrator is to see that the library occupies its proper position in the academic organization and that the organization of the library is so planned and operated as to justify and maintain this position.

In every aspect of human endeavor, since man is continuously faced by problems of decision and choice, elements of administrative needs are continually being expressed. The more complex a situation is, the greater is the need for planned, objective, systematic administrative decisions. Looking at the field of administration from a broad, over-all point of view, the administrator must not be confused by the intricacies of detail, he must neither view techniques and routines subjectively nor substitute them for a carefully planned program. The administrator must be able to delegate authority, know to whom routine work is to be given, and measure the results without being responsible for actually doing the job. He must be able to see the program as individual units of work, and once the projects are completed, he must know that the program has unity and that the work is coordinated. Like any science, the science of administration adopts a critical, scientific, objective attitude.

Library objectives, aims, and administrative policies vary widely among various types and sizes of libraries. Basically, the objectives of all libraries are acquisition of books and related materials; preservation, distribution, and evaluation of these materials; and planning a program to meet the needs of those the library serves. In establishing the administrative program, it is important to know whom the library serves; the amount of money to be spent; and the goals to be achieved.

The aims, objectives, and policies of a small liberal arts college library will depend entirely upon the objectives of the institution it serves. The administration of the library must be coordinated with the aims of the institution. The library must literally be the heart of the college, and the relationship between the library and the college must be clearly understood.

But what are the elements of administration? What do we mean when we talk about an administrative program? How does a librarian discover what is involved in acting as an administrator? In other words, what does an administrator do? Paul Howard, in a master's paper for the Graduate Library 
School, University of Chicago, written in 1939, entitled "The Functions of Management," listed as the seven functions of an administrator the following:

1. Directing - the thinking and deciding function, including planning, initiating, and devising.

2. Ordering-formulating and issuing commands.

3. Supervising - seeing whether orders are carried out, and seeing that orders are carried out.

4. Controlling-producing in the workers the willingness and capacity to carry out the orders.

5. Organizing-establishing definite relationships within an institution for the purpose of facilitating management and operation.

6. Evaluating-determining the efficiency and effectiveness of the enterprise.

7. Representing-personifying the enterprise to the owners and public.

Each of these administrative functions must be thoroughly understood and translated into positive action if a librarian is to be a successful administrator and if the library is to have a successful program. More and more emphasis is being placed on this phase of library work by the professional library school. There is a difference between a trained librarian who appreciates and understands routine operations as a proper and accurate means toward some welldefined goal, and the single-minded technician to whom each routine job is an end in itself. Acquisition is not enough; preservation is not enough; planning and evaluating are not enough. The successful coordination of all of these to make the library operate properly within the framework of the institution it serves and to be a proper factor in the educational program should be the raison d'être of every librarian of every small liberal arts college library.

Library administration is not some nebulous thing in the outer regions. It can be reduced to practical measures. Reduced to simple statements, a college library program ought to include the following:

1. Cooperate with the administration, faculty, and student body in making the college a better academic institution.

2. Know of the objectives of the college and of each academic department.

3. Understand and be familiar with each course offered by each department and the teaching methods employed.

4. Make the library the laboratory of the whole college by coordinating materials.

5. Make the library the center of the arts program.

6. Assist in the selection of books and periodicals and maintain a carefully planned program of inclusion and exclusion.

7. Promote interest in reading.

8. Furnish guidance in the use of the library.

9. Install and maintain modern library techniques of acquisition, technical processing, and distribution.

10. Instruct professional and clerical assistants in the methods of operation which are to be followed.

The administrative program in each small liberal arts college library must of necessity vary in detail. It varies because of the institutional limitations and library facilities. Therefore, it becomes the responsibility of the librarian to set up a program which can be successfully undertaken. He cannot, however, carry out a program alone. He must have the aid of an interested and industrious group of co-workers. He must use practical means to accomplish given goals. Goals and programs look wonderful on paper, but the successful library administrator is the one who translates goals and programs into achievements.

In the small liberal arts college library the same kind of work is done (admittedly the quantity varies) as is done in the largest university library: policy making, book selection, cataloging, classification, reference, circulation, serials, binding, etc. The internal organization of the library becomes a serious problem when the administrator tries to get all the work done with a staff of three. In the largest libraries, each operation is in the hands of a specialist. As libraries get smaller, each member of the staff must be in charge of a number of operations, but the quality of the work must remain satisfactory. The administrator in planning the program must see each phase of the work objectively and as a means to an end but he must plan how it is to be done subjectively. The general division of work will follow traditional 
patterns, but the librarian must try to plan the work so that the staff member best qualified to do the work is given that work to do, and he must insofar as possible try to see that like kinds of work stay together. $\mathrm{He}$ must see that there is no overlapping of work assignments.

Now, because there are no sets of graphs, charts, questionnaires, or master's papers stating categorically that no group has had a harder time of it, served with less pay and fewer rewards, and been subjected to as many discriminations as librarians in the small liberal arts colleges, it must remain an assumption. Working in cramped quarters with poor ventilation, unsatisfactory lights, inadequate heating, while the field houses, football fields, and chemistry laboratories are modernized; overworked with a fourteenhour week day and open on Sundays; criticism from faculty members (who teach fifteen hours a week) because the building is closed on holidays; serving the college through twelve months for less pay than faculty members get for nine months; working through summer school for no additional pay while the faculty gets a fourth more; working through vacations because of unfinished work which accumulates during the term; seeing departments get secretaries at more pay than the trained cataloger while the librarian does his own typing; seeing a new football coach given a full professorship while the library staff with as good if not better educational qualifications remain as assistants and instructors with no statusthese are but some of the more obvious difficulties.

Because of these, and other conditions, librarians with real creative ability go into other branches of the profession. A college librarian who does an outstanding job is often taken by the large universities at a salary which simply cannot be refused, and given a position with some dignity and tradition. Those of us who are left do not always have all the qualities needed to be good administrators, but even if we had, it would still be an uphill fight against serious odds. By and large there are two groups really at fault. The first is the professional library school. They have failed on several counts. The first is to establish prerequisites for pre-professional courses offered at the under- graduate level. Secondly they have been too concerned with high academic qualifications and too little concerned with administrative abilities. Over the years these schools have trained a group of students who could memorize or do their assignments but who lacked administrative and creative abilities. If the library school had been as interested in personality, creative ability, administrative judgment, executive capacity, and individual initiative as they were in "A's," librarians might not now be in the low find themselves. In library school there is income bracket in which they unhappily still too much emphasis on busy work. Recruiting for librarianship is, unfortunately, done at the wrong time and frequently in the wrong place. Until there is a reasonably sensible approach developed, there will still be problems.

The second group has been the college administration itself. College salaries are too low; working conditions are too poor; and, in general, treatment is too shabby to get and keep first-class librarians even if they were easily available which, of course, they are not.

At present, the small liberal arts college libraries throughout the United States are staffed with two or three professionally trained librarians. College administrators have only just begun to realize the important part which the library can and should play in higher education, and they have also just begun to discover that the library cannot be administered by just any one. The notion that the position of librarian is best filled by a person who is keen on old books, who just loves to read, or who is a poor teacher of English literature or a retired professor of education, is slowly changing. The modern small liberal arts college library presents a scene of tremendous activity. It is a business which purchases, employs, serves, educates, and influences. The modern college librarian is a business agent with a commodity to sell for which there is an excellent market. Books, periodicals, newspapers, and all kinds of audio-visual materials must be available to the students and faculty upon demand, and if the demand is not sufficient, the librarian must be prepared to create the demand. To carry on such an operation in our complex academic 
society requires an efficient organization, capable personnel, and administrative judgment. Such problems as finance, hours, selection of employees (mostly student help), work to be done, and clientele to be served often present serious stumbling blocks. Plagued by a multitude of duties and hampered by inefficient conventions and techniques, the librarian must realize that he cannot be bothered too much with routines but must take an objective viewpoint and coordinate all the activities into a unified whole. He must consider every operation to be performed, who is to do it, when it is to be done, and the best way of doing it.

The average small liberal arts college library is in operation about thirty-six weeks a year, about sixty hours a week, maintains a staff of three full-time professional librarians, employs about twenty student assistants, serves a student body of approximately five hundred, and must answer to the college administration, student body, faculty, library associations, accrediting associations, and state and government investigators. Furthermore, all this must be accomplished on an appropriation which allows for anything but extravagance.

This, then, is the dilemma which faces the small liberal arts college library. There are certain technical operations within the library which must be performed completely accurately. Book selection, order routines, cataloging and classification, card filing, circulation, and general library statistics must be properly done. The work cannot be shabby, the routines cannot be shoddy. The administrative judgments must be sound and the policy of the library sure.

But how? Prospective employees sent out by our professional schools who have had no experience and not very good training generally prove not only difficult but sometimes literally impossible. Salaries in all positions are too low to attract and to keep the best possible persons on the staff. As a matter of fact, most salaries are so low that one hesitates to ask that one's staff members do the best possible job that they can do. A cataloger who handles five thousand books a year is doing a full-time job without assisting in the administrative program which the librarian is directing. A public service assistant who takes charge of all public serv- ices cannot do much more. It leaves the whole program in the hands of the librarian who must, I fear, be all things to all people. We have, actually, only one answer and that is in the recruiting of first-class student assistants. These students properly trained, given two or three properly planned undergraduate pre-professional courses, can ease the burden, supply enthusiasm, and in many instances become sufficiently interested in librarianship as a career to stay in the profession.

The main burden must fall on the librarian. Through experience, I have found that there must be regular meetings held. I tried insofar as possible when I was librarian at Bethany College to talk with the cataloger (who was most of the time the only other professional in the library) about library problems, trials, and tribulations. There were, in addition, always three students who carried the title of "library assistant" and who met with the assistant librarian and me to talk over the program, to ask questions, and to give suggestions and advice. From time to time, the entire staff was called together and the whole program and its various parts was discussed with the whole staff. Out of this came many valuable and important suggestions which contributed to the total program.

At present I find myself in the peculiar and laugh-provoking position of calling a staff meeting at which I am present, sitting at the desk and asking questions, and then running across the room to sit in another chair and answer my own questions. I find myself giving me advice-and, conversely, me criticizing myself.

Once upon a time when the world was very young and no one in this broad land of ours was safe from buffalo, a college librarian's lot was a happy one. Tales of my predecessors at Bethany College used to warm the cockles of me poor old heart. One in particular always fascinated me. I shall refer to her as Mrs. W. because in the first place I cannot remember her name but I have dredged up from somewhere the feeling that her name did begin with a W. Anyhow, Mrs. W. dozed quietly day in and day out in her rocking chair beside a pot-bellied stove-waking only to complain when some woe-begone student with nothing else to do 
let in a blast of cold, mountain air. There were no records to keep, no students to serve, the library opened late and closed early, and all was serene along the banks of the Old Buffalo. I suspect that stories of this kind could be told world without end about every little college library across this land of ours.

Then something happened. Libraries have come alive, and the whole idea of libraries and librarianship has undergone a tremendous change. The library, once the storehouse, has turned into the laboratory of the whole college. The librarian now becomes ex-officio a member of the faculty of each department, and he must of necessity teach, instruct, and lead in the arts and sciences. Every phase of library activity has increased a hundredfold. And herein we find our dilemma. Librarians who are neither trained nor prepared to carry on these activities are suddenly finding themselves in the midst of this boiling cauldron, having to spread themselves thin to meet demands for their time, efforts, and abilities. Much trouble comes from the fact that we do not have enough time to do all the things which are demanded of us. There are not enough staff hours. By trying to do all the things which are asked of us, we find, unfortunately, that much of our effort is in vain because we are trying to do too much, carry on too many activities, and operate in areas for which we are not properly prepared.

Most assuredly something needs to be done. After thirty years in active library work (most of it spent in a small liberal arts college atmosphere) and in three library schools, I do not know the answer. Do you?

By KEYES D. METCALF

\section{Staff Participation in Library Management}

\section{in a Large Research Library}

$\mathrm{T}$ HE THINGS THAT I SHALL HAVE TO SAY will not be very profound; they may all seem obvious and routine, and the clichés will be plentiful, I fear. They will not, at least, be quoted from other authors. For better or worse, I have carefully avoided trying to bone up on the literature of the subject. Instead, I shall speak only from first-hand knowledge accumulated during more than fifty years of experience in library work.

Let me start by saying that I believe unhesitatingly and heartily in staff participation in library management in large research libraries-in all libraries, for that matter. Staff participation, like other good things, can be misused; my belief in it does not mean that $I$ approve when it is made an excuse for laziness of the chief librarian, or when he tries, by means of it, to escape the

Dr. Metcalf, retired director of the Harvard University Library, is at present, professor, Graduate School of Library Service, Rutgers University. responsibility that he ought to accept as his. In order to explain why I believe in staff participation, I am going to consider four major topics: (1) the effect of staff participation on staff members, (2) its effect on the chief librarian, (3) its effect on the library, and, (4) its effect on the library profession.

The first of these topics-the effect of staff participation on staff members-particularly appeals to me because I have always been interested in training young people for library work. I have always wished that I had the ability to teach and that I could have done more to train the young men and women who are to become leaders in the next generation. It is pleasant now, in my latter days, to have an opportunity at Rutgers to try my hand at it.

My interest in the subject goes back to the time, fifty-one years ago last summer, when I made up my mind to become a librarian. I was then spending a summer vacation from high school working as a hired man on an Ohio farm. I knew that I had a lot to learn about libraries, and wondered how to go 